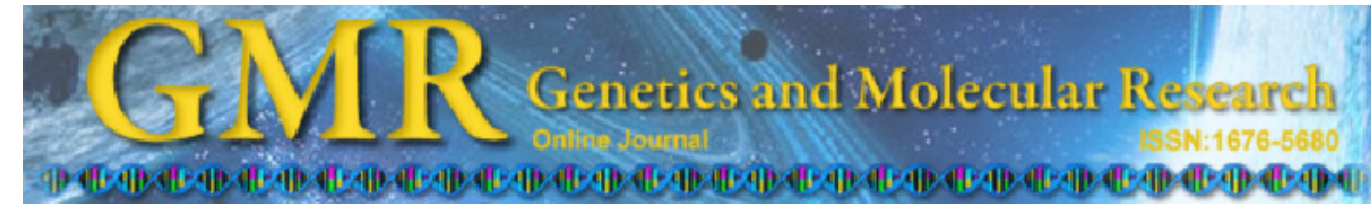

\title{
First report of sacbrood virus in honey bee (Apis mellifera) colonies in Brazil
}

\author{
M. Freiberg ${ }^{1}$, D. De Jong ${ }^{2}$, D. Message ${ }^{3}$ and D. Cox-Foster ${ }^{1}$ \\ ${ }^{1}$ Department of Entomology, The Pennsylvania State University, \\ University Park, Pennsylvania, USA \\ ${ }^{2}$ Departamento de Genética, Faculdade de Medicina de Ribeirão Preto, \\ Universidade de São Paulo, Ribeirão Preto, São Paulo, Brasil \\ ${ }^{3}$ Universidade Federal de Viçosa, Viçosa, Minas Gerais, Brasil \\ Corresponding author: D. De Jong \\ E-mail: ddjong@fmrp.usp.br
}

Genet. Mol. Res. 11 (3): 3310-3314 (2012)

Received July 31, 2012

Accepted August 25, 2012

Published September 12, 2012

DOI http://dx.doi.org/10.4238/2012.September.12.14

\begin{abstract}
Sacbrood disease, an affliction of honey bees (Apis mellifera) characterized by brood that fails to pupate and subsequently dies, is an important threat to honey bee health. The disease is caused by the sacbrood virus (SBV), a positive-, single-stranded RNA virus in the order Picornavirales. Because of the economic importance of honey bees for both pollination and honey production, it is vital to understand and monitor the spread of viruses such as SBV. This virus has been found in many places across the globe, including recently in some South American countries, and it is likely that it will continue to spread. We performed a preliminary study to search for SBV in two apiaries of Africanized honey bees in the State of São Paulo, Brazil, using RT-PCR and Sanger sequencing and found the first evidence of SBV in honey bee colonies in Brazil. The virus was detected in larvae, foraging and nurse bees from two colonies, one of which had symptoms of sacbrood disease, at the beginning of the winter season in June 2011. No SBV was found in samples from nine other nearby colonies.
\end{abstract}

Key words: Apis mellifera; Sacbrood virus; Sacbrood disease; Brazil 


\section{INTRODUCTION}

The honey bee, Apis mellifera, is extremely important to agriculture worldwide, not only for its honey production but also for its vital role as a pollinator. In Brazil, honey bee health is declining (Teixeira et al., 2008), and although this decline is mild compared to the recent die-off's reported in Europe and North America (van Engelsdorp et al., 2009), it is still of great concern considering the economic importance of honey bees for Brazilian agriculture. Honey bee health is impacted by numerous factors, including parasites, pathogens, pesticides, and nutrition. Viral pathogens are of particular interest because they often cause disease and have been associated with recent honey bee problems reported in the United States (CoxFoster et al., 2007). Understanding and monitoring the global prevalence and spread of these viruses will be vital to predicting and controlling them and may give insights into why South American bees seem to be healthier than those in North America and Europe.

At least 22 different viruses are known to infect the honey bee, with the best studied and most prevalent being positive-sense single-stranded RNA viruses in the order Picornavirales (Chen and Siede, 2007; Runckel et al., 2011). While many of these viruses can cause disease, they frequently exist in the colony as latent infections that can multiply rapidly under stress conditions. This often occurs when the colony is compromised by outside stressors such as infestation with the mite, Varroa destructor, which can also spread the virus (Genersch and Aubert, 2010) and impair host immune function (Yang and Cox-Foster, 2005). Because the effects of viral infection are not always observable, there is an additional challenge to the diagnosis and monitoring of RNA viral infections in honey bees; molecular or immunoassay techniques are required to confirm the presence of a virus as opposed to symptoms, which are often not apparent. Reverse transcription PCR (RT-PCR) has become the method of choice to detect RNA viruses in honey bees, because it is both highly accurate and relatively inexpensive (Benjeddou et al., 2001; Grabensteiner et al., 2001; Genersch, 2005; Shen et al., 2005; Chen and Siede, 2007).

Sacbrood virus (SBV) is an important pathogen of honey bees because it is the etiological agent of sacbrood disease in A. mellifera (Bailey et al., 1964). Sacbrood disease is an important malady of honey bees and is characterized by larvae that fail to pupate and turn pale yellow and eventually dark brown before they die. The virus was first isolated and characterized by Bailey et al. (1964), although the disease itself was first described by White in 1913 and attributed to a viral infection in 1917 also by White. Since the disease was first characterized, it has been found throughout Europe, Africa, Asia, North America, and recently South America, where it has been found in both Uruguay (Antúnez et al., 2006) and Argentina (Reynaldi et al., 2010). SBV had previously been detected in larvae collected by one of the authors (DDJ) in Buenos Aires Province, Argentina, in the mid 1990s (Message et al., 1996) from one of numerous colonies with symptoms.

We performed a preliminary study of managed honey bee colonies and report the detection, using RT-PCR and Sanger sequencing, of SBV in managed colonies in the State of São Paulo, Brazil. While a number of other Picornavirales had been found in colonies in Brazil, including deformed wing virus (DWV), acute bee paralysis virus (ABPV), and black queen cell virus (BQCV) (Teixeira et al., 2008), this represents the first detection of SBV in Brazilian A. mellifera colonies. The virus is very common in many other parts of the world, suggesting that it will likely continue to spread across South America. Beekeepers in Brazil 
and neighboring regions should take steps to learn about the disease and prepare for its arrival, and practices and policies should be considered in order to slow down and monitor the spread of SBV.

\section{MATERIAL AND METHODS}

\section{Collection of bees}

All bees were collected from apiaries of Africanized honey bees maintained on the University of São Paulo campus in Ribeirão Preto, Brazil. Foraging workers were sampled by collecting bees entering the hive, while nurse bees were sampled by collecting bees directly from the brood combs. Brood was sampled by careful removal with tweezers. Samples were stored at $-80^{\circ} \mathrm{C}$ until being processed.

\section{RNA extraction}

RNA was homogenized in $500 \mu \mathrm{L}$ TRIzol reagent (Invitrogen) per adult bee or bee larva and extracted according to manufacturer instructions. Honey bee RNA was extracted from a pool of 10 bees homogenized together, from individual bees, or from individual bee larvae. The RNA pellet was precipitated with isopropyl alcohol overnight at $-20^{\circ} \mathrm{C}$. The pellet was then washed with $75 \%$ ethanol, resuspended in $20 \mu \mathrm{L}$ nuclease-free water, and stored at $-80^{\circ} \mathrm{C}$ for further analysis. The concentration of RNA in each sample was measured using a spectrophotometer (NanoDrop ND-1000).

\section{Reverse transcriptase PCR}

First-strand reverse transcriptase cDNA synthesis was performed on extracted RNA samples using $5 \mu \mathrm{g}$ total RNA and superscript II (Invitrogen), according to manufacturer instructions. The RNA template was primed using an oligonucleotide-deoxythymidine (oligo$\mathrm{dT}$ ) primer.

\section{Virus-specific PCR}

Honey bee cDNA was amplified with SBV primers (SBV-F 5'-CACTCAACTTACAC AAAAAC-3'; SBV-R 5'-CATTAACTACTCTCACTTTC-3') specific to a 210-bp section in the capsid region of SBV, as described by Shen et al. (2005). Samples were amplified with Taq DNA polymerase (Promega), with each primer at a concentration of $0.4 \mu \mathrm{M}$. Reactions were carried out with a thermal protocol consisting of an initial incubation at $94^{\circ} \mathrm{C}$ for $8 \mathrm{~min}$, followed by 35 cycles of $94^{\circ} \mathrm{C}$ for $55 \mathrm{~s}, 51.5^{\circ} \mathrm{C}$ for $55 \mathrm{~s}, 72^{\circ} \mathrm{C}$ for $85 \mathrm{~s}$, with a final incubation at $72^{\circ} \mathrm{C}$ for $10 \mathrm{~min}$.

\section{Gel electrophoresis}

DNA samples were visualized on a 1.5\% agarose gel and compared to a standard 100bp molecular weight DNA ladder. 


\section{Sequencing}

PCR products were precipitated with isopropyl alcohol and resuspended in $10 \mu \mathrm{L}$ nuclease-free water. Samples were prepared for sequencing using the BigDye Terminator v3.1 Cycle Sequencing Kit (Applied Biosystems) and a GeneAmp PCR System 9600 (Applied Biosystems), in accordance with manufacturer instructions. Samples were then sequenced using an ABI Prism 310 Genetic Analyzer (Applied Biosystems).

\section{RESULTS AND DISCUSSION}

An initial survey of bees from 10 colonies in an apiary on the University of São Paulo campus in Ribeirão Preto was done by pooling 10 forager bees from each colony and testing them for SBV using the RT-PCR assay described above. Of the 10 colonies surveyed, one had a positive band of approximately $210 \mathrm{bp}$, suggesting the presence of SBV in this colony. This colony was retested for SBV using the RT-PCR assay on eight individual forager bees; three of the eight bees were positive for SBV. While the initial colony with SBV was observed to be healthy, an additional colony was tested in a nearby apiary on the campus that was exhibiting symptoms suggestive of SBV. From this colony, eight larvae and eight nurse bees were tested for SBV using the RT-PCR assay described above. Among these larvae, one of eight tested positive for SBV. Among the nurse bees, four of eight tested positive for SBV. The PCR product of each reaction was sequenced and aligned to the SBV complete genome (GenBank accession No. AF092924.1) (Ghosh et al., 1999).

This represents the first detection of SBV in Brazil. A previous investigation of numerous samples of larvae with sacbrood-like symptoms collected from various parts of Brazil found no evidence of this virus, based on viral particle morphology and serological methods (Message et al., 1996). The symptoms were in fact caused by toxic pollen (de Carvalho and Message, 2004) and the syndrome named "Brazilian sacbrood-like disease". It is not surprising that SBV has now been found in Brazil, considering its worldwide incidence and recent findings in neighboring countries (Antunez et al., 2006). With global trade and travel occurring at unprecedented rates, the global spread of viruses and other pathogens can occur faster than ever before. It is thus extremely important to monitor the global spread of pathogens, including those that infect honey bees. For SBV in particular, further and more extensive studies will be vital to understanding how the virus spreads, as well as the prevalence and impact of the virus in southeast Brazil and throughout the entire country.

\section{ACKNOWLEDGMENTS}

We thank the Penn State International Graduate Program in Brazil for providing travel expenses for M. Freiberg and Dr. Zilá Simões at the University of São Paulo, Ribeirão Preto campus, for providing supplies to do the molecular analysis. Research supported by CAPES, CNPq and FAPESP.

\section{REFERENCES}

\footnotetext{
Antúnez K, D’Alessandro B, Corbella E, Ramallo G, et al. (2006). Honeybee viruses in Uruguay. J. Invertebr. Pathol. 93: 67-70.
} 
Bailey L, Gibbs AJ and Woods RD (1964). Sacbrood virus of the larval honey bee (Apis mellifera Linnaeus). Virology 23: 425-429.

Benjeddou M, Leat N, Allsopp M and Davison S (2001). Detection of acute bee paralysis virus and black queen cell virus from honeybees by reverse transcriptase pcr. Appl. Environ. Microbiol. 67: 2384-2387.

Chen YP and Siede R (2007). Honey Bee Viruses. In: Advances in Virus Research (Maramorosch K, Shatkin AJ and Murphy FA, eds.). Vol. 70. Elsevier Academic Press Inc., San Diego, 33-80.

Cox-Foster DL, Conlan S, Holmes EC, Palacios G, et al. (2007). A metagenomic survey of microbes in honey bee colony collapse disorder. Science 318: 283-287.

de Carvalho ACP and Message D (2004). A scientific note on the toxic pollen of Stryphnodendron polyphyllum (Fabaceae, Mimosoideae) which causes sacbrood-like symptoms. Apidologie 35: 89-90.

Genersch E (2005). Development of a rapid and sensitive RT-PCR method for the detection of deformed wing virus, a pathogen of the honeybee (Apis mellifera). Vet. J. 169: 121-123.

Genersch E and Aubert M (2010). Emerging and re-emerging viruses of the honey bee (Apis mellifera L.). Vet. Res. 41: 54.

Ghosh RC, Ball BV, Willcocks MM and Carter MJ (1999). The nucleotide sequence of sacbrood virus of the honey bee: an insect picorna-like virus. J. Gen. Virol. 80: 1541-1549.

Grabensteiner E, Ritter W, Carter MJ, Davison S, et al. (2001). Sacbrood virus of the honeybee (Apis mellifera): rapid identification and phylogenetic analysis using reverse transcription-PCR. Clin. Diagn. Lab. Immunol. 8: 93-104.

Message D, Ball BV and Allen M (1996). Ocorrência de Viroses em Abelhas no Brasil e na Argentina. In: XI Congresso Brasileiro de Apicultura, Salvador, 399.

Reynaldi FJ, Sguazza GH, Pecoraro MR, Tizzano MA, et al. (2010). First report of viral infections that affect argentine honeybees. Environ. Microbiol. Rep. 2: 749-751.

Runckel C, Flenniken ML, Engel JC, Ruby JG, et al. (2011). Temporal analysis of the honey bee microbiome reveals four novel viruses and seasonal prevalence of known viruses, Nosema, and Crithidia. PLoS One 6: e20656.

Shen M, Cui L, Ostiguy N and Cox-Foster D (2005). Intricate transmission routes and interactions between picorna-like viruses (Kashmir bee virus and sacbrood virus) with the honeybee host and the parasitic varroa mite. J. Gen. Virol. 86: 2281-2289.

Teixeira EW, Chen Y, Message D, Pettis J, et al. (2008). Virus infections in Brazilian honey bees. J. Invertebr. Pathol. 99: 117-119.

van Engelsdorp D, Evans JD, Saegerman C, Mullin C, et al. (2009). Colony collapse disorder: a descriptive study. PLoS One 4: e6481.

White GF (1913). Sacbrood, a Disease of Bees. US Department of Agriculture, Bureau of Entomology, Circular 169: 1-5, New York.

White GF (1917). Sacbrood. USDA Bull. 431: 1-55.

Yang XL and Cox-Foster DL (2005). Impact of an ectoparasite on the immunity and pathology of an invertebrate: evidence for host immunosuppression and viral amplification. Proc. Natl. Acad. Sci. U. S. A. 102: 7470-7475. 